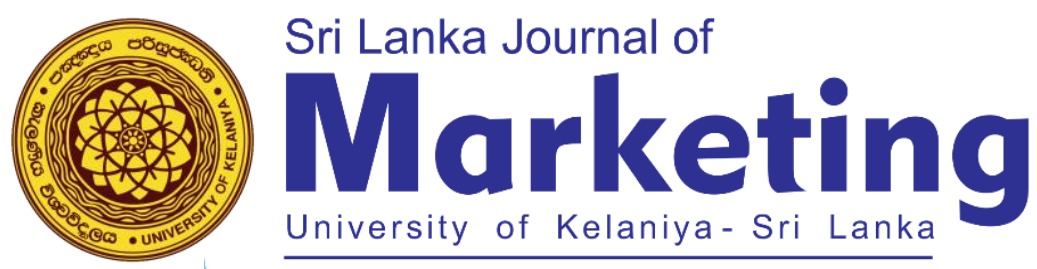

\title{
Factors Influence on the Development of Corporate Entrepreneurship on the Large Organizations in Sri Lanka:
}

\section{A Narrative-Based Model}

\author{
Sanath Divakara \\ General Manager - Manufacturing, Macson Mesh Industries (Pvt) Ltd, Sri Lanka \\ sanathdivakara@gmail.com
}

\begin{abstract}
Corporate entrepreneurship is defined as entrepreneurs within the organization, thus corporate entrepreneurs play an imperative role in the growth of organizations. A booming trend in researching the concept of corporate entrepreneurship stimulated the performance of the business lexicon during the past two to three decades. This research focused on the exploration of influencing factors for the development of corporate entrepreneurs in large organizations in the context of Sri Lankan.
\end{abstract}

The study focused on a qualitative approach and conducted in-depth interviews in order to explore firsthand contemporary knowledge in relation to their businesses. Corporate entrepreneurs are identified as the driving arms with business knowledge of the organizations and initiate required implementation aligned to the prevailing market trends. Hence influencing factors imperatively contribute to the development of corporate entrepreneurship in the process of decision making, creativity, innovation and strategic renewal. The study revealed answers to the question of how corporate entrepreneurship develop within the organization and how that effect on organizational growth.

The study conducted in-depth interviews selecting ten most prominent corporate entrepreneurs in the large scale industries of the context using purposive sampling and analyzed the transcripts followed to narrative inquiry associating the software NVivo 12. The literature enabled to converge the findings into three areas of individual, organizational and environmental. Derived important themes related to the study scope and context that would enable to enhance to practice as the betterment of the relevant industry.

Keywords: Corporate Entrepreneurship, Large Organizations, Narratives, Organizational Performance 


\section{INTRODUCTION}

The concept "corporate entrepreneurship" makes a vital role in the business environment in presence of highly competitive market thus; it has become a wide research topic in the academic environment. Large organizations are equipped with these concepts "corporate entrepreneurship" and smaller and mediums scale organizing focused to the concept of "intrapreneurship". However, the literature evidenced a booming trend on researching the concept of corporate entrepreneurship in the growth of an organization. Corporate entrepreneurs are not entrepreneurs in the proper sense of notation, they are specialists with exceptional training and ability to use the knowledge accumulated for innovations or transforms the organization into success (Antoncic \& Hisrich, 2003). Corporate entrepreneurs manage large scale organizations having employees with vast knowledge and experience towards to achieve and satisfy shareholders objectives without the ownership of the company (Carrier, 1994). Corporate entrepreneurship enables a potential mean for revitalizing establishments (Zahra \& Covin, 1995). Corporate entrepreneurs are with the skill of developing, manage and carry forward the business as expected by the shareholders. The corporate entrepreneur is an individual within the organization who creates and takes responsibility for transforming an idea into a profitable venture through taking creative and innovative approaches (Thornberry, 2001). Therefore, critical assessment on influences of corporate entrepreneurs and organizational development has become important as a contemporary requirement to the business world.

Researching into the influencing antecedents of corporate entrepreneurship Alpkan, Cagri Bulut, Gunday, Ulusoy, and Kilic (2010) has introduced three specific contextures organizational, individual, and environmental. This paper studies the attributes of individuals as influencing antecedents in the growth of organizational performances and exploring these two questions (Rae, 2005).

1) How do people work as corporate entrepreneurs in the organization; what are the contextual attributes in the development of corporate entrepreneurship?

2) Can construct a useful framework for understanding of corporate entrepreneurship and develop and applied, both in the practice of organizational and individual growth?

Hughes and Mustafa (2017) researched and identified these five antecedents as the core internal antecedents that enabled corporate entrepreneurship focused to large organizations. Corporate entrepreneurial "process wherein individual or group of individuals, in association with an existing organization, create a new organization or instigate renewal or innovation within the organization" (Sharma \& Chrisman, 1999, p. p.26). Technological advancement and hostility as environmental factors were considered as a spur for the development of corporate entrepreneurship (Zahra, 1993). Antecedents are as essential factors in the development and enabling of entrepreneurial skills. Corporate entrepreneurs are employees of the organizations hence the development of skills depend on individual 
capabilities, organizational milieu and environmental conditions. The study develops a model relating all influences in the development of entrepreneurial skills as corporate entrepreneurship in the growth of organizations.

\section{LITERATURE REVIEW}

Research emphasized that corporate entrepreneurship with business diversification and intrapreneurship as dreamers who promote innovatory activity within the organization (Pinchot, 1985). Corporate entrepreneurs extend the organizational capabilities without breaking links with the organizational core competencies (Floyd \& Wooldridge, 1999). Corporate entrepreneurship is defined at the large organization level that referred to as a top-down process, which is a strategy used by management to foster more initiative and improvement from their workforce (Bosma, Stam, \& Wennekersf, 2010; Gapp \& Fisher, 2007). Corporate entrepreneurship is a concern at the organizational level to flourish the organizational performance (Kazanjian, Drazin, \& Glynn, 2002). Corporate entrepreneurship has been framed under capability and rigidity paradox (Floyd \& Wooldridge, 1999). Similarly, there is another perspective about the concepts found by (Amo, 2010), the core field of a corporate entrepreneur is based on organizational change is manageable, the management can control the action of employees and decide which innovation to be implemented. The corporate entrepreneurship was a paramount in business literature based on organizational performances. Corporate entrepreneurship is a powerful antidote to large companies' staleness, lack of innovation, stagnated top-line growth, and the inertia that often overtakes the large, mature companies of the world (Thornberry, 2001). Corporate entrepreneurship was a concept introduced in large scale organizations as a part of performance management. The corporate entrepreneurship, referred as intrapreneurship in many studies, is an option to the organizational strategy to refine the business concept and focused on changing customer needs and expectations (Miller \& Camp, 1985). Later in the 80s, the concept of intrapreneurship was evolved in between the concept of entrepreneurship and corporate entrepreneurship. As the business lexicon becomes more competitive, the evolution of new concepts scrutinized the management process to be effective and efficient. However, most cited articles of (Zahra, 1993), Zahra and Covin (1995) triggered the interest to study the concept of corporate entrepreneurship exploring the factors of influences: organizational, individual and environmental and outcome as organizational growth (Divakara \& Madurapperuma, 2017).

\subsection{Managers as Corporate Entrepreneurs}

Middle-level manager's entrepreneurial behavior, historic evidence confirmed that recognition of psychological foundation for human and behavior, which is integrated with social content. Consequently, it was identified as psychophysics, which is the study of the relationship between external simulations with the internal psychological experience of individuals, which is denoted by 
Lewin's expression (Shaver \& Scott, 1991). The author further emphasized some of the psychological characteristics of distinguishing entrepreneurs are the locus of control, risk-taking propensity, and achievement motivation as high energy level, persistence. Entrepreneurial firms, where top management practice entrepreneurial management style which is displayed by the strategic decisions and operating management philosophies (Covin \& Slevin, 1988). The research finding implies that top managers believe that they must improve corporate entrepreneurial skills substantially to maintain the competitiveness of their firms and managers and executives have a challenging task to balance the external characteristics of dynamism against hostility (Sahra \& Pearce, 1994). Managers make decisions on the basis of a salient belief that they experienced information availability on financial and non-financial and information perception in the organization (Antoncic, 2003). The relationship between transformational leadership and corporate entrepreneurs have been examined under three transformational leadership styles of transformational, transactional, and passive-avoidant (Moriano, Molero, Topa, \& Lévy Mangin, 2011). The transformational leader is the leader inspiring their followers to adopt the vision of the organization with their own focus energy toward their achievement (Moriano et al., 2011). Jones (2005) argued that managerial choice rather than industrial structure is an essential factor for the profit and growth of the organization, which is further based on achieving business success by the encouragement of employees work in productively.

\section{METHODOLOGY}

Realities are socially constructed (Creswell \& Poth, 2018). Social constructionist provide much potential in entrepreneurship research (Pittaway, Aïssaoui, \& Fox, 2017). Social constructionist approach was adapted in this study to construct organizational, individual and environmental influences to the corporate entrepreneurship. Hornsby, Donald F. Kuratkoa, and Zahrab (2002) highlighted the importance for qualitative research and better understating of the organizational culture and context. In accordance to a criterion based on theory of upper echelon (Hambrick \& Mason, 1984) and ISO 9001 (International Standard Organization), the research adapted purposive sampling and ten in-depth interviews in locations of ten different organizations. Corporate entrepreneurs play a silent role and actively engaged in the organizational management. Focusing a holistic picture of the concept, narrative is used as the strategy for the analysis.

The theory of experience explained (Clandinin, 2016), three dimensions of the metaphoric narrative inquiry space, a space drawn upon Dewey's criterion, interaction (personal and social) and continuity (past, present and future) and notion of situation in the in-depth interview. Narratives are the suitable methodology in this study concern to the exploring experiences, knowledge in relation to the corporate entrepreneurship. Narratives analysis associating NVivo 12 software was adapted in the analysis of transcripts in this in the research. 


\section{FINDINGS AND DISCUSSION}

The analysis of transcripts followed to the literature review under the three categories of individual, organizational and environmental proposed following framework in the development of corporate entrepreneurship within in the organization.

Figure 1: Triadic Model of Corporate Entrepreneurship

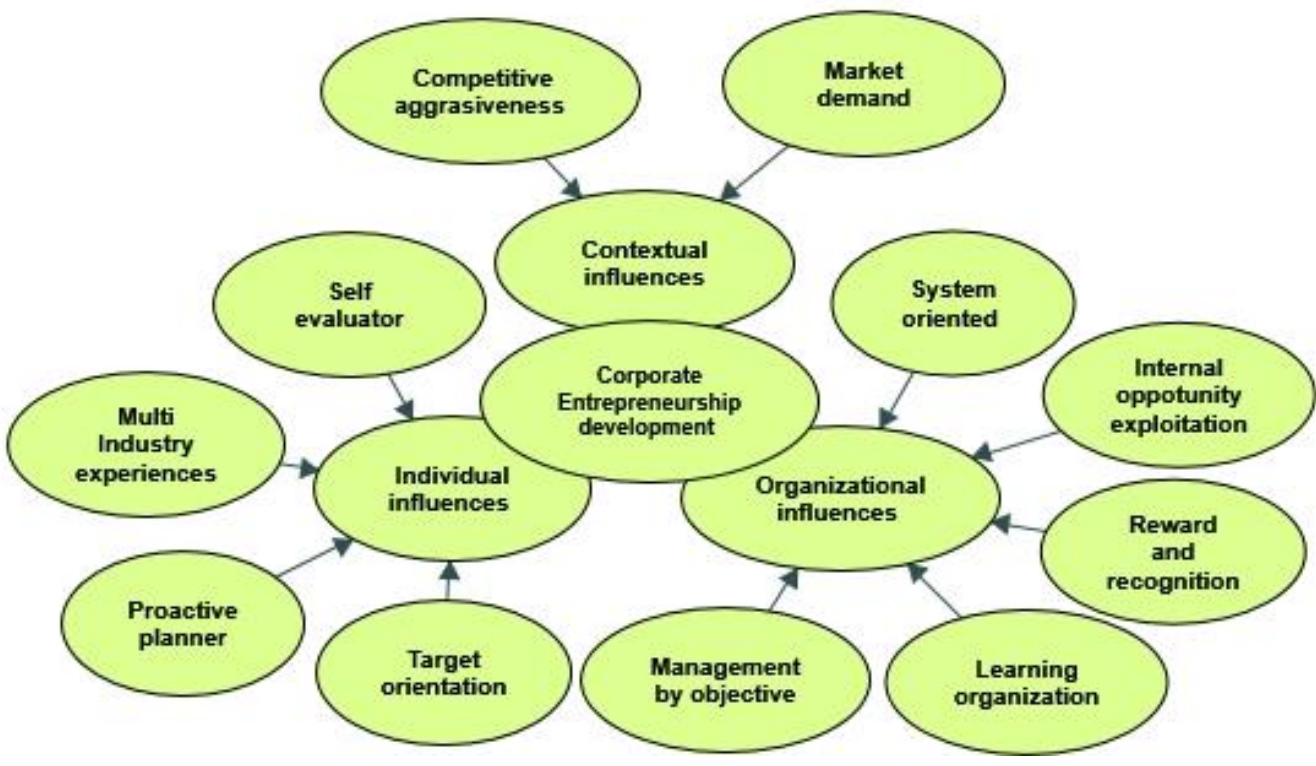

Corporate entrepreneurship is prominently highlighted within the organizations where it is assimilated the enclosed strategies of strategic renewal, innovation and venturing (Sahra \& Pearce, 1994). Each influencing factors that have contributed in the development of corporate entrepreneurship are crucial for the organizational development. Thus the scrutiny of transcripts of in-depth interview was replete the research objectives.

\subsection{Individual Influences}

Corporate entrepreneurship is an internal process constructed with the dimensions of autonomy, ego, prior experiences, proactiveness, competitive aggressiveness, risk-taking, etc. (Lumpkin \& Dess, 1996). The internal process of corporate entrepreneurship wiliness to engage in learning and wanting to do a thing in a better way (Carrier, 1994). Individual factors are a combination of psychological, social and cognitive construction over a period of time spent as an employee. The entrepreneurial behaviour of the individual continues to be seen as a significant path to competitive advantage and performance improvement in all types of organizations (Kuratko, 2006). There are two parts of knowledge accumulation, such as knowledge accumulated from the experiences and knowledge accumulated from updating their educational qualification as cognitive factors. The study explored significant intrinsic 
factors embedded within particular participants acting as entrepreneurs within the organization. The individuals showed interest on targets which was exemplified through all the transcripts.

\subsection{Target orientation}

As exemplified in the previous explanation, targets or objectives are the driving forces to corporate entrepreneurship. Organizations are basically involved targets where that has a high portion of overhead costs such as energy, maintenance, transportation, rental, etc. Setting targets and achieving targets are very important in the survival of the businesses. The market base is with highly sensitive customers and competition that has to be tackled by working to given targets. Achieving targets is one of the personal capabilities and depends on their capacities. As Lochana's explanation,

"I review all monthly and analyze all the target achievements. Also, we discuss strategies to find new customers and new markets. My focus is to increase our market share, so we work on that all the time"

Target orientation is a personal attribute that contributes to the organization requirements as well. Thus it was identified as a skill in this study refers to the analysis of the following elicitations. Achievement orientation is an influencing factor of individual antecedents for creating effective directions to the organization. The study found that respondents had their own objectives in their life as well. The story of all the respondents exemplified that they had a better past track record integrated with their objectives. Objective driven life intrinsically managed everyone's performance. Intrinsic confidence was constructed through the knowledge, constructed over the experiences working in the industry. The respondents explained their intrinsic feeling about how they enjoy the work as specific attribute of corporate entrepreneurship.

Multi industry experience was visualized within the respondents as a significant factor of corporate entrepreneurs. The respondents had experiences working in many organizations in many functional areas. Steve had experience in working in four industries as sales executive, sales manager, general manager and chief executive office. Having the capacity to work in many work areas is one of the special abilities that embedded as corporate skills. Similarly, Tharuka and Ganesh also had the same experiences of having knowledge about many disciplines. All were upper echelons and gained the knowledge about human resources, engineering, production, supply chain, quality made enormous support working in the industry. Tharuka's explanation is as follows,

"I worked in multiple companies as different positions starting as junior executive to chief executive officer and I gained vast experiences in handling all functions and disciplinary".

The corporate entrepreneurs were with a high level of educational background, and most of them were had completed high level of educational qualifications. That means that they had the capability of absorbing knowledge in any discipline. That was a special interest had with them on gaining the knowledge. 
Self-evaluator: Corporate entrepreneurship found as self- evaluators. Corporate entrepreneurship depends on employee satisfaction and organizational characteristics that will create a culture of innovative generating values for the organization through human and capital (Arslan, Zaman, \& Luk, 2014). Elements of employee satisfaction are intertwined with the elements of organizational culture, climate (Auer Antoncic \& Antoncic, 2011). Self-evaluation is somewhat subjective, and the understanding about their self is somewhat partial decision. However, all the respondents showed a significant facts of explication on self-evaluation. The entire list of respondents was at a high level of self-evaluator with their carriers and their current positions in the workplace. However, following examples stated that Steve who was working as Chief Operation Officer in FMCG industry.

I identify my strengths and weaknesses based on the end results. Because, all of us believe that we have a self-set of hard skill and self-set of soft skill, but nobody will identify the real skill processed unless they analyze the end result. So I use to look at my end result, what I have achieved, what I missed and what I have promised to the board. I look at the area that I need to improve based on end result and I put conscious effort to improve my weak points.

Tharuka's feeling, how she encounters herself was with the relationship and caring of ownership and relationship with colleagues in the organization and the culture that exists in the organization. She was very vigilant about the outer world and enjoyed the work, and she expected a positive outcome for her to enjoy satisfaction as expressed follows,

However, I realized that there was something behind me. I now understood it, because my Ph.D. is aimed for this topic. I selected the theory of self-discrepancy. I believed that this theory said about me.

Tharuka was very particular about her and planned carrier development as against the performances. She engages with reading for PHD and the learning will make her more shape in the business.

Self-evaluation is an intrinsic motivation that creates within the employees. They were eager to see new things and absorb motivational feelings after making the success of the effort. Self-evaluation is one of a significant factor that influences an individual to develop corporate entrepreneurship. Many of the respondents were elicited powerfully and said that they are highly satisfied with their current and previous employments. Most of the employees enjoy their employment doing new developments, learning new technologies, studying environment, involving teamwork, etc.

Proactive planner: The dimension of proactive planning made imperative contribution in the study finding. Corporate entrepreneur are the leading characters in all the large scale organizations, thus proper planning skills required to be display in their management functions. Proactiveness is justified previous studies as a dimension of corporate entrepreneurship. Proactiveness refers to a posture of anticipating and acting future needs and wants with a high level of commitment (Lumpkin \& Dess, 
1996). The pro-activeness is the dimension that reflects the top management support in order to enhance competitiveness (Mokaya, 2012). Steve explained his experiences as follows,

"I am already getting prepare the new business proposal to the shareholders that will be proposed within next six months. We must provide them a new business proposal that investing to development. We have already been invested huge investment and future investments are not big investments for us. Therefore, we able to reach to the new plans easily".

The extent of which organizations attempt to lead rather than follow the competitors identified as proactiveness in the field and is a powerful tool for problem-solving. Proactive firms are more toward to be first movers in the field of business, and they are active that passive to the term of development (Ağca, Topal, \& Kaya, 2009). Proactive firms tend to be market leaders rather than followers in the business field in today's context (Lumpkin \& Dess, 1996). Proactive planning enables the organization to refrain from disputes and disciplinary issues among the employees.

\subsection{Organizational influences}

When an individual becomes an employee is the process starts construction of knowledge from the organizational background. In addition to that individual tends to update academic knowledge, theories, formulas, concepts, models that enhance cognitive capacity and creativity. Corporate entrepreneurs are embedded with knowledge and experiences in two areas of functional and administrative that makes an enormous effect on growth. That enables making the right decision under any circumstances for any kind of issue. Updating academic knowledge helps to induct theories through hands-on experiences. The organization opens the doors for research and development, which has two-fold benefits of organizational development and inducting theories. Open innovation introduced by Henry Chesbrough and it contributed to the development of corporate entrepreneurship. Open innovation is sourced out for knowledge updates in the industry. The organizations where the study conducted were opened to society and encouraged for researches and academic activities.

The fundamental requirements should be organized by the entrepreneurship from the organization to emerge right corporate entrepreneurs. However, the analysis found various factors as organizational influences about the industry as new findings inherent to the context. The factors discovered from the study concerning the organizational influences are discussed here in detail,

Learning organization: The most important objective of an organization is to move forward for its highest possible performance in a sustainable manner. Development of corporate entrepreneur is a competitive factor; therefore leaning organization plays an important role in developing corporate entrepreneurs (Alipour, Idris, Ismail, Uli, \& Karimi, 2011). The organizations start at a very small level and gradually expand their process capabilities to become small, medium and large. Following are 
given examples of stories of how organizational learning contributed to develop entrepreneurial skills in the sample organizations. The extract of Amira's is as follows,

Those employees related areas are monitoring, environmental, training and extra activities. Mainly we focused succession plans for future requirement such as improving skills and capabilities of our employees. We inquire about the gaps of skills and implement necessary training as a learning organization.

The organizations provide two types of training external and internal. The extract of Amira's was somewhat comprehensive and that organization was concerned more in arranging training and monitoring the performance through in order to fulfill of objectives. The management focused a succession plan. Learning organizations have become as an competitive now a days as such organization concentrate improving knowledge of their workforce continuously. There are different types of learning processes such that in-house session and outside sources. Organizations monitor about the upgrading qualification of their management staff as well as explained by Shanaka,

We monitor about the upgrading qualification of our own management. Annual update is required. That can be related or non- related but out human resource development is vigilant on continuous development.

Shanka's organization, they had a separate event called "Ape Wedikawa" focused on employees, and that was a successful event. Learning had been identified as a fundamental aspect of entrepreneurship development, and behaviour focused on to acquiring knowledge, business knowledge, attitude and habits (Gibb, 2016).

System orientation: The developed organizations were tended to use work systems and procedures in order to standardize their processes incorporating the ISO certification. There are many advantages, such as cost reduction, efficiency increase, productivity improvement that led to high organizational growth. All the organizations were certified and adhered to practice ISO standard; hence the practice about systems can be visualized. Indika's explanation is as follows,

Without policy and procedures, you can't run a business. We need to build business sense into the system. Now lot of organizations train people in terms of sales and marketing, time management, leadership and everything but in term of business sense it's very difficult to build but you need to focus on building business sense in each and every level, so I drive that as a key thing.

The respondent indicated that they were certified with ISO system and adhere to practice effectively. In cultured entrepreneurship organizations, system implementation gives good and bad experiences; however, it avoids dependency in work which enables to conduct of the process referring to the 
documents. Corporate entrepreneurs involve and properly adapted to the work system of the organizations. However, performance is more convenient with the systemization and following systems and procedures. The important factor resulted in this behavior improve productivity and efficiency of the organization as well. Management support is the degree of willingness to support the entrepreneurial activities of the employees in the organization (Anthonia, 2016 ). There is a huge stock of references found out about organizational support as one of the major influences for the development of intrapreneurship. In this study also found out that management support is essential in the development of corporate entrepreneurship concerning the Goonathilaka's stories,

We need to change our methods and systems time to time where beginners and new comers cannot compete with us. This can be done by giving team members more independence to pursue ideas that contribute to the company's mission and customer value creation as part of their job.

Goonathilaka explained how he was feeling about top management support. She had confidence in working in any section with her experiences. In all the workplaces she worked had identified the capabilities and skills; hence she had support from the top management. Corporate entrepreneurs display their capabilities and skill hence the get required management support. Similarly, the other respondents have also said the same story of getting good support from the top management. Top management support facilitates and promotes entrepreneurial behavior (Ireland, Covin, \& Kuratko, 2009). The responsibility of the top management is to get the work done effectively and efficiently from their subordinates. It was observed that the culture of the organization visualized the support of the top management. All the organizations were with the highest level of top management support and that was the one secret behind the good performance of the corporate entrepreneurs.

Reward \& recognition: Reward is the one significantly discussed in previous papers in major scale as influence as to the development of corporate entrepreneurship. However, in this study, found that there were two words integrated as rewards and incentives in the latest context. Hence in this study, it was expanded by adding incentives wherein the industries promote incentives more than rewards. If employees are engaging innovative work in the organizations has to pay or reward, or a share for them as share get by entrepreneurs (Thornberry, 2001). If employees have a high level of trust in rewards and appreciation systems of their organization that will enable organizational success and turns those to benefits (Alpkan et al., 2010). The grater the performances on the reward system in the organization make higher their innovative performances (Alpkan et al., 2010).

Example story of Amir's shared below exemplified about the reward system existed in organizations that boost entrepreneurial skills of employees effected to improve skills of corporate entrepreneurship.

"I am very care about our employees and there should be motivated work force, those motivated 
rewards are first being working environment and work schedule and I give my effort to keep the both are balance".

Amir was particular about their subordinates and he thinks about their performance. He involved about the entrepreneurial culture in the organization. Thus rewards, incentives and recognition highly practiced in all the organizations according to the all respondents contributed in the study.

Management by Objective: When an organization received system certification, it tends to have culture of objective-driven management systems in practice as a compulsory requirement. Management by objectives is a common technique applied in the large scale organizations in order to achieve their organizational objectives. However, according to the latest version of system certifications consist of strategic directives where organizations have to fulfill a strategic plan. Practicing system certification makes awareness and given guide lines to the organizations and corporate entrepreneurs are with the skill and educational background in absorbing the knowledge of preparation of relevant objectives. The system certification is introduced a continue monitoring tools in order to set objectives on achievements followed to Deming's cycle plan, do, check, act (PDCA). The important factor is to develop the culture within the organization for the adaptation.

Goonathilaka was a senior manager from a reputed food manufacturing organization work he explained how their organization plan about their objectives and their behaviors to achieve as below,

"Organization should always remind employees regularly to achieve the common and department goal and objectives. By showing that people in all departments will get together and try to help others in achieving the organization goal".

The analysis explained all the industries use to practice management by objectives in their organization for achieving their organizational performances. The critical point is not the setting objective that has been monitored at the management review, which is called the "Management Review Meeting" as per the requirement of system certification.

Objective-driven culture is a highly effective process in business. Setting, achieving and monitoring are carrying out by the responsible echelons. There are many types of tools used in objective-driven culture, such called key performance indicators (KPI), baseline indicators (BLI), performance indicators (PI), etc. However, corporate entrepreneurs are well conversant in practicing an objective-driven environment specifically in manufacturing in their performance.

Opportunity seeker: Five broad types of internal entrepreneurship which is so called corporate entrepreneurship that had been proposed as administrative, opportunistic, imitative, acquisitive and incubative by (Kuratko, Montagno, \& Hornsby, 1990; Schollhammer, 1982). Corporate entrepreneurs 
recognized opportunities and reconfigure resources to exploit the opportunities (Rigtering \& Weitzel, 2013). Opportunities for organizational development are within the organizational environment. A corporate entrepreneur has endogenous skill in grabbing the correct opportunities and implements it in the aspect of economic and social. Bricolage, trifling, improvising are some of the tools and activities involved to economize the operations of opportunities by the relevant corporate entrepreneurs. Respondent "Nushan" exemplified below how they exploited the opportunities and what type of culture within the organizations.

As a corporate entrepreneur and when I worked for a food company, I looked at the opportunities around me and that helped me to build my business. Also, by elaborating the educational qualification you can move forward seeking for opportunities and then you start certain disciplines.

There were two types of opportunities discussed by the respondents as internal and external. The respondents explained about internal opportunities those involved in improving internal capabilities by the implementation productivity, quality in the process. Nushan was focused on external opportunities working as marketing manager, whereas he was looking at external market opportunities through engagement in FMCG. Corporate entrepreneurs can identify and turnout opportunities with their skills, knowledge, and experiences that have been exemplified by the above stores.

\section{CONTEXTUAL INFLUENCES}

Contextual occurs through participation in the outer world customers, industry and other network in which individuals are influenced to emerge the creativity (Rae, 2005). The study confirmed the validity of those factors in the Sri Lankan context and extracted more as new factors additionally. The environment influences broadly divided into internal factors (Organizational structures, culture, system) and external factors as Industry globalization, product/ market, life cycle, stage and government regulations (Zahra, 1991). External factors Dynamism, Technological opportunities, Industry growth, Changing customer demand, Unfavorability of change and competitive rivalry had been associated with corporate entrepreneurship or intrapreneurship (Zahra, 1991). Environmental influencing factors are not so significant in the corporate entrepreneurship development compared to other factors of individual and organizational in the medium scale organizations. Following are the exploration of environmental factors related to the context,

Market demand: All the organizations selected in the study were in the high growth stages as a result of strategic renewal or natural growth. The growth stage signifies a better market share for their products and hence internal competition to supply the required product on time. Market demand encourages and shape up entrepreneurial skills on creating new process improvements and products as a strategy of pull strategy (Antoncic, 2007). Corporate entrepreneurs' attention is on how to innovate production system 
to sustain the market demand under a certain pressure. All the respondents exemplified that they have an outstanding market, and accordingly, the production had been planned. Tharuka's explain about the relationship of the market demand as follows,

As organizations, to identify opportunities you need to work towards the market growth. According to the market growth, the organization should harness opportunities and develop the internal capabilities and match with that external environment opportunity.

Respondent revels on important statements on the influences of market demand. Demand stimulates corporate entrepreneurship skills and innovation. Corporate entrepreneurs are objective driven which tends to integrate the market demand. Marked demand created a rivalry inside the business process. Corporate entrepreneurship development would be effective through more creativity and innovations in searching for the solutions.

All the organization take part in the study were in high performance and had high demand for their product thus, it explained a rivalry in the within the business and the corporate entrepreneurs in the organization had well identified the market demand and share.

Competitive aggressiveness: Competitive aggressiveness is a measure of the extent of the competition among the existing organization. The continuous competition among the firms markets pursuit corporate entrepreneurship, creating opportunities in firms' markets (Zahra, 1991). Competitive rivalry creates internal rivalry for organizational survival. Internal competition is a jolt created by the market demand for accepting challenges (Antoncic, 2007) and the fact that corporate entrepreneurs never accept failures. The following are explained story of Goonathilaka about the competitive aggressiveness.

Therefore, most important thing and the biggest challenge faced today is how to manage market changes. To manage the changes, first we need to understand what is happening in the market. Market changes are inevitable. Therefore, it is needed to have a clear plan to face this challenges happen in the market and competitors.

Three respondents exemplified three different stories about how those organizations take measures to sustain the market. Competition is a challenge for an organization hence corporate entrepreneur act against those challenges. Mahen maintains brand image and product portfolio, Sadepa's strategy is cost leadership having economies of scale and scope, Dilhan take effort to maintain goodwill in the business. There were different types of rivalry in three types of industry, as explained above. However, those were affected as results of environmental changes such as political, social and economic. The 
connotations of the examples indicate how serious the internal rival as against competition outside. Corporate entrepreneurs are vigilant about what's happening outside through their networks.

\section{CONCLUSION AND APPLICATION}

The scope of the study has a wider application of the model in theoretical, empirical and practical ways beyond the context of the study. Study context focused mainly three hegemonic areas of individual, organizational and contextual as the contributor in the development of corporate entrepreneurship that justified in the previous literature as well. The significant factors derived with considered to the areas are making an organizational development under the high competitive environment. Corporate entrepreneur is highly visible in large scale organizations and they are the driving personnel of the organizations towards to the specific directions given by top authorities. Large organizations are with different management systems that enables less mistakes due to matured leaderships styles. Large organizations are matured organization and operating at the peak of their growth cycles.

The model may also be an important input to the practitioners that proposed factors influences in the development of corporate entrepreneurship. Individuals may enable their capability development within the organization. Individual processes contribute to the organizational growth and they are with the motivation of self-satisfaction. Organizational influences contribute to the development of corporate entrepreneurs by fulfilling necessary infrastructural facilities and training. However, it is not enough only having two influences of individual and organizational for the development corporate entrepreneurship. Environmental factors as well play a major role of push strategy in the development of corporate entrepreneurship. Corporate entrepreneurs are aggressive on achieving targets and objectives thus, the factors of market demand and competitive aggressiveness were the two factors significant on following through to achieve set objectives accordingly in related to the context.

The study can further have developed in searching more factors relevant to the context focusing on each main influencing factors of individual, organizational and environment. Modern industries are essentially required to identify corporate entrepreneurs and develop the skills that may lead to exponential growth of their organizations. However, this concept is not so popular in the context and less attention has been drawn by the researchers. Nevertheless, researching more about the context would be a result for the strategic renewal of the organizations as well. 


\section{REFERENCES}

Ağca, V., Topal, Y., \& Kaya, H. (2009). Linking intrapreneurship activities to multidimensional firm performance in Turkish manufacturing firms: an empirical study. International Entrepreneurship and Management Journal, 8(1), 15-33.

Alipour, F., Idris, K., Ismail, I. A., Uli, J. A., \& Karimi, R. (2011). Learning Organization and Organizational Performance: Mediation Role of Intrapreneurship. European Journal of Social Sciences, 21(4), 547-555.

Alpkan, L., Cagri Bulut, Gunday, G., Ulusoy, G., \& Kilic, K. (2010). Organizational support for intrapreneurship and its interaction with human capital to enhance innovative performance. Management Decision, 48(5), 732755.

Amo, B. W. (2010). Corporate entrepreneurship and intrapreneurship related to innovation behaviour among employees. International Journal of Entrepreneurial Venturing, 2(2).

Anthonia, O. (2016 ). An exploratory study of Intrapreneurship Development: the Role of Organizational Factors. International Journal For Research In Business, Management And Accounting ISSN: 2455-6114, 2(7).

Antoncic, B. (2003). Risk Taking in Intrapreneurshio: Translation the Individual Level Risk Aversion into the Organizational Risk Taking. Journal of Enterprising Culture, 11(1).

Antoncic, B. (2007). Intrapreneurship: a comparative structural equation modeling study. Industrial Management \& Data Systems, 107(3), 309-325.

Antoncic, B., \& Hisrich, R. D. (2003). Clarifying the intrapreneurship concept. Journal of Small Business and Enterprise Development, 10(1), 7-24.

Arslan, M., Zaman, R., \& Luk, M. (2014). Effect of Employee Satisfaction on Intrapreneurship: An Analysis from Service Industry of Pakistan. Public Policy and Administration Research, 4(19).

Auer Antoncic, J., \& Antoncic, B. (2011). Employee satisfaction, intrapreneurship and firm growth: a model. Industrial Management \& Data Systems, 111(4), 589-607.

Bosma, N., Stam, E., \& Wennekersf, S. (2010). Intrepreneurship - An International Study. Scientific analysis of Entrepreneurship \& SMEs.

Carrier, C. (1994). Intrapreneurship in Large Firms and SMEs: A Comparative Study. International Small Business Journal: Researching Entrepreneurship, 12(3), 54-61.

Clandinin, D. J. (2016). Narrative Inquiry: A Methodology for Studying Lived Experience. Research Studies in Music Education, 27(1), 44-54.

Covin, J. G., \& Slevin, D. P. (1988). The influence of Organizational Structure on the Utility of an Entrepreneuiral Top Management Style. Journal of Management Studies, 281-234.

Creswell, J. W., \& Poth, C. N. (2018). Qualitative Inquary Research Design (Fourth Edition ed.). Singpure Sage Publication.

Divakara, S., \& Madurapperuma, W. (2017). A systematic Literature review on Intrapreneurship and Organizational performance. Paper presented at the Asia Pacific conference on Multidiciplinery Research, Sri Lanka.

Floyd, S. W., \& Wooldridge, B. (1999). Knowledge creation and social networks in corporate entrepreneurship: The renewal of organizational capability. Entrepreneurship Theory and Practice, 123-143.

Gapp, R., \& Fisher, R. (2007). Developing an intrapreneur-led three-phase model of innovation. International Journal of Entrepreneurial Behavior \& Research, 13(6), 330-348. 
Gibb, A. A. (2016). Small Firms' Training and Competitiveness. Building Upon the Small business as a Learning Organisation. International Small Business Journal: Researching Entrepreneurship, 15(3), 13-29.

Hambrick, D. C., \& Mason, P. A. (1984). Upper Echelons: The Organization as a Reflection of Its Top Managers, Academy of Management Review, 9(2).

Hornsby, J. S., Donald F. Kuratkoa, \& Zahrab, S. A. (2002). Middle managers' perception ofthe internal environment for corporate entrepreneurship: assessing a measurement scale. Journal of Business Venturing, 17.

Hughes, M., \& Mustafa, M. (2017). Antecedents of Corporate Entrepreneurship in SMEs: Evidence from an Emerging Economy. Journal of Small Business Management, 55, 115-140.

Ireland, R. D., Covin, J. G., \& Kuratko, D. F. (2009). Conceptualizing Corporate Entrepreneurship Strategy. Entrepreneurship Theory and Practice, 19 - 46.

Jones, O. (2005). Manufacturing regeneration through corporate entrepreneurship. International Journal of Operations \& Production Management, 25(5), 491-511.

Kazanjian, R. K., Drazin, R., \& Glynn, M. A. (2002). Implementing Strategies for Corporate Entrepreneurship: A knowledge based Perspective. Strategic Entrepreneurship: Creating a new mindset, 174 -194.

Kuratko, D. F. (2006). Corporate Entrepreneurship. Foundations and Trends® in Entrepreneurship, 3(2), 151203.

Kuratko, D. F., Montagno, R. V., \& Hornsby, J. S. (1990). Developing an Intrapreneurial Assessment Instrument for an Effective Corporate Entrepreneurial Environment. Strategic Management Journal,, 11, 49-58.

Lumpkin, G. T., \& Dess, G. G. (1996). Clarifing the Entrepreneurial Orientation Construct and Linking it to Performance. Academy of Management Heview, 21(1).

Miller, A., \& Camp, B. (1985). Exploring Determinant of Sucess in Corporate Venturing. Journal of Business Venturing, 1, 87-105.

Mokaya, S. O. (2012). Corporate Entrepreneurship and Organizational Performance Theoretical Perspectives, Approaches and Outcomes. International Journal of Arts and Commerce, 1(4).

Moriano, J. A., Molero, F., Topa, G., \& Lévy Mangin, J.-P. (2011). The influence of transformational leadership and organizational identification on intrapreneurship. International Entrepreneurship and Management Journal, 10(1), 103-119.

Pinchot, G. (1985). Intrapreneuring: Harper \& Row Publishers

Pittaway, L., Aïssaoui, R., \& Fox, J. (2017). Social Constructionism and Entrepreneurial Opportunity.

Rae, D. (2005). Entrepreneurial Learning: A narrative- based conceptual model. Journal of Small Business and Enterprise Development, 12(3), 323 - 336.

Rigtering, J. P. C., \& Weitzel, U. (2013). Work context and employee behaviour as antecedents for intrapreneurship. International Entrepreneurship and Management Journal, 9(3), 337-360.

Sahra, S. A., \& Pearce, J. A. (1994). Corporate Entrepreneurship in Smaller Firms: The Role of Environment, Strategy, and Organization. Entrepreurship Innovation and change, 3(1).

Schollhammer, H. (1982). Internal corporate entrepreneurship. Etncyclopedia of Entrepreneurship, Prentice Hall: Englewood Cliffs, NJ,.

Sharma, P., \& Chrisman, J. (1999). Towards the reconciliation of the definitional issues in the field of corporate entrepreneurship. Entrepreneurship Theory and Practice,, 19(3). 
Shaver, K. G., \& Scott, L. R. (1991). Person, Process, Choice: The Psychology of New Venture Creation. Entrepreneurship Theory and Practice, 20-45.

Thornberry, N. ( 2001). Corporate Entrepreneurship: Antidote or Oxymoron? European Management Journal, 19(5).

Zahra. (1991). Predictos and Financial Outcomes of Corporate Entrepreneurship: An Exploratory Study. Journal of Business Venturing, 6, 259-285.

Zahra. (1993). Environment Corporate Entrepreneurship and Financial Performance: A Taxonomic Approch. Journal of Business Venturing, 8, 319-340.

Zahra, \& Covin, J. G. (1995). Contextual Influecnces on the Corporate Entrepreneurship Performance Relationship: A longitudinal Analysis. Journal of Business Venturing, 10, 43-58. 